\title{
Sexuality at the Bar: An Empirical Exploration into the Experiences of LGBT+ Barristers in England \& Wales
}

Marc Mason

University of Westminster

Dr Steven Vaughan UCL Centre for Ethics and Law 


\section{UNIVERSITYOF WESTMINSTER用}

Contact the Authors:

Marc Mason: m.mason@westminster.ac.uk @MarcMasonm StevenVaughan: steven.vaughan@ucl.ac.uk @lawvaughan 


\title{
Sexuality at the Bar: An Empirical Exploration into the Experiences of LGBT+ Barristers in England \& Wales
}

\author{
Marc Mason, University of Westminster \\ Dr Steven Vaughan, University College London
}

25 September 2017

The Bar of England \& Wales is an historic, traditional institution of courtroom advocates and specialist advisers that can trace its origins back to the 13th century. As a field of study, there is comparatively little academic work on barristers. Where work has been done on the Bar, and in relation to diversity at the Bar, this has tended to focus either wholly or primarily on women barristers and suggests patterns of inequality, exclusion and forms of direct and indirect discrimination. Like the other branches of the legal profession in England and Wales, the Bar does not reflect the society it serves. In their world-first research, 'Sexuality at the Bar', Mason and Vaughan show a variety of complex practices which govern where (and when and how) LGBT+ members of the Bar feel comfortable being open about their sexuality as well as highlighting a significant number of LGBT+ barristers who have experienced work related bullying and/or discrimination. Their work also suggests an increasing role for Bar-specific LGBT+ networks and the value of LGBT+ role models, both at the Bar and in the judiciary.

\section{THE PROJECT}

In 2016, Mason and Vaughan launched an online survey to capture the career experiences of LGBT+ members of the Bar. This was completed by 126 practising barristers, Queens Counsel, pupils (barrister trainees), and students taking the pre-vocational Bar Professional Training Course. The survey focused on four main areas: (i) homophobia in the workplace (ii) if (and how and where) barristers were 'out' at work; (iii) the potential connections between sexuality and practice; and (iv) the purpose of LGBT+ networks and role models.

Following the survey, Mason and Vaughan used the data they had captured to build a range of questions for semi-structured interviews. 38 of these took place in the latter half of 2016: 2 with pupil barristers; 4 with students; 5 with QCs; and 27 with barristers.

\section{THE BAR: A BRIEF OVERVIEW}

Unlike law firms, which are owned (usually, but not exclusively) by the solicitor partners, with employee solicitors and others working for those partners, the majority of barristers $(13,000$ out of 16,000 in total) are self-employed. They commonly work in chambers, groupings of self-employed barristers which share resources including premises, clerking staff and IT support. Barristers do not share profits with each other. Their work is almost exclusively derived from solicitors who instruct the barristers on 
behalf of the clients. Here, barristers' clerks act as intermediaries in the allocation of work from solicitors to barristers, and otherwise act as support for the members of chambers. Progression at the Bar appears in various forms. Certain barristers "take silk" and are known as QCs (Queen's Counsel). The other significant route of progression for barristers is to join the judiciary.

\section{THE FINDINGS}

\section{Demographics}

The survey participants comprised 28 women and 98 men, aged between 21 and 71 , and called to the Bar between 1968 and 2015. 108 identified as White; 2 as Black or Black British; 6 as Asian or Asian British; 2 as Chinese or Chinese British; and 8 as Mixed Race. No survey participant identified as trans.

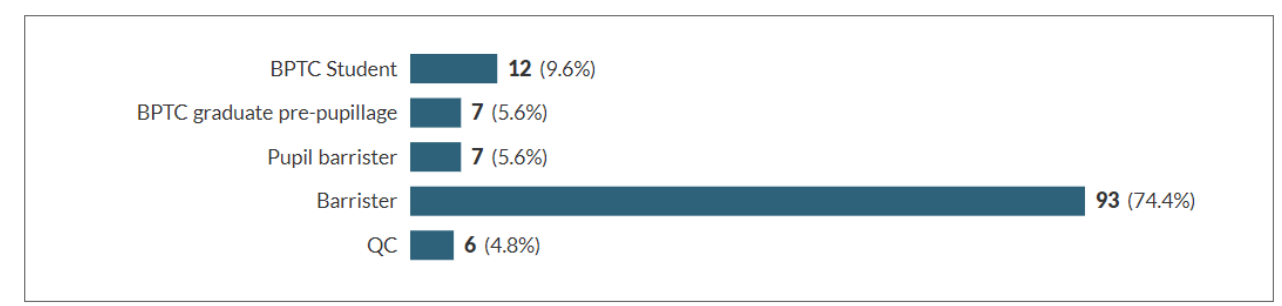

13 of those who took part in the survey also sat part time as judges. The vast majority (100 of the 126) practised in London. Half were in the first generation of their family to attend university. One third attended 0xbridge as an undergraduate. 10\% had some form of disability. The survey participants worked in more than twenty different practice areas, with significant groupings in Civil, Commercial/Chancery, Criminal, Family Law and Public Law.

\section{Homophobia at the Bar}

Just over half of our survey respondents had experienced some form of discrimination at work or in their professional studies on account of their sexuality. One third had experienced some form of bullying or harassment in these arenas. $26.5 \%$ of survey respondents had experienced sexuality linked discrimination 'sometimes', 'often' or 'frequently'. $25.6 \%$ had experienced such discrimination 'rarely' (47.9\% said 'never'). These data arguably suggest that homophobia is stronger at the Bar than in the general population: Stonewall research shows that, in the general population, one in five (19 per cent) lesbian, gay and bi employees have experienced verbal bullying from colleagues, customers or service users because of their sexual orientation in the last five years.

Just under half of our respondents (48.7\%) had experienced 'banter' linked to their sexuality 'sometimes', 'often' or 'frequently'. A further $26.5 \%$ had experienced the same banter, though 'rarely'. Homophobic banter, it seems, is prevalent at the Bar.

"I was still subject to quite a lot of what the blokes in chambers thought was hilarious humour. And every time somebody got drunk at a party or a dinner I got some bloke coming up to me asking why I was a lesbian and hadn't I ever considered having sex with men - really quite inappropriate comments." QC56

We were struck in the interviews by three matters linked to these data. The first was how many barristers played down or made light of their own homophobic experiences. The second was that, 
despite being fearless advocates in the pursuit of their client's interests, many barristers had failed to step forward and defend their own rights, to speak up in the face of homophobia.

"I've got one colleague here who I think is an unpleasant homophobe... And I'm told that he was making some fairly unpleasant homophobic comments which was making the pupil feel uncomfortable... [l: And then what happened?] Well nothing! Rightly or wrongly. It would feel a little bit like if I went to the head of chambers, telling tales out of school. Rightly or wrongly.... Although I think the head of chambers would at that point have actually actioned it and spoke to the person... I almost ask myself the question, why I didn't do anything about it. All I'm telling you is that I didn't". B19

The third matter was that, when we asked for examples of homophobia, a number of students spoke of instances involving the Inns of Court.

"One of my fellow students was at an Inns' qualifying session and was talking to a bencher who sort of jokingly or flamboyantly said, "I don't trust fags like you". This BPTC student didn't really know how to respond to that. It was a bencher, what are you going to do basically? Didn't say anything, felt a bit rubbish about it." S27

The Inns of Court provide specialist educational and other support, as well as social and networking opportunities, to would-be barristers and those in practice. It is necessary to be a member of one of the Inns, and to attend a number of social or educational sessions there, to qualify a barrister. We were struck, in the interviews, by the level of criticism levelled at the Inns (for not doing enough to signal their support for LGBT+ members of the Bar) compared with our interviewees' views on the Bar regulator (the Bar Standards Board) and the overarching Bar professional association (the Bar Council). This criticism was particularly notable at both the most senior (QCs) and most junior levels (pupils).

\section{Different Forms of Difference}

There is a rich literature on how multiple forms of difference (e.g. being a working class, lesbian barrister) can mean that different individuals experience difference differently. Our survey respondents split fairly evenly on whether they thought that different members of the LGBT+ Bar are treated similarly. In the survey free text comments, it was suggested that "gay men have it better" at the Bar. This rang true in many of the interviews, where people spoke of clear instances of transphobia and of biphobia.

"I've a couple of times witnessed negative comments about... specific transgender people. One was a senior colleague who, when we were out at lunch, was talking about a judge who apparently had transitioned. .. in quite a horrible, disparaging way like referring to her as 'it' and saying that she was sort of trying to play a trick on people by changing her name and stuff." B16

Lesbian and bisexual women barristers were equally clear that their gender played a significant part in how they experienced the Bar. A number spoke of how their visible difference (their gender) was often more challenging than their sexuality.

"I don't necessarily wear [my sexuality] on my sleeve. I'm sure people know that I'm gay... It's not something that is really immediately apparent."

B72

The same point (about the differences between visible and invisible characteristics) was made by many of the non-white barristers we spoke with. 
"And then I'm thinking do I want to confuse the picture anymore being a black person, being somebody of 30 , by adding to the fact that you're gay. "P15

Pushing back against this, however, was the fact that a number of our interviewees described themselves as "camp" and suggested that, for them, the idea that their sexuality was not visible was simply not true.

Reflecting the volumes of work on class and the legal profession, many of our interviewees discussed how their educational and personal backgrounds affected their experience of the Bar (alongside and overlapping with their sexuality).

"Now, just going back to what I said before, my sceptical eyes would say the British establishment has always tolerated gay white upper-class men in the private school system as a sort of idiosyncratic feature of our colonial system. So it's great that one gets to be Court of Appeal judge, but much more interesting when we get a working-class black lesbian as Master of the Rolls, or whatever the expression would be, and much more important in a way that we get a swathe of pansexual Asian trainees or whatever it might be. So I don't see that as demonstrating success; I see that as something to celebrate but only as part of a much bigger picture." QC54

\section{Being 'Out' at the Bar}

We were interested in whether (and where and how) LGBT+ barristers were 'out' in their professional and personal lives, and in how being 'out' was performed.

Our survey data shows that the vast majority (over $80 \%$ in each case) were out with all or most of their family, friends, and other barristers in their chambers. Slightly fewer were out with all or most of the pupils in their chambers and with chambers staff. However, just under half $(46.8 \%)$ were out with all or most of their instructing solicitors and only a quarter (23.4\%) were out with all or most of their lay clients. A small number were not out with any barristers in their chambers $(4.3 \%)$, any pupils in their chambers (11.9\%) or any chambers staff (9\%). $69 \%$ had been out during Bar school/the Bar Vocational Course/the Bar Professional Training Course.

When we explored being 'out' at work in the interviews, our interviewees split. Many thought that their professional and personal lives were separate.

"I think as a profession the whole nature of the profession is that your individual characteristics and traits are irrelevant, it's about representing your client, even down to the wig and the gown, and that the barrister is a tool for the client and a medium through which that client is heard or represented in court. "S27

In the wider literature, this idea (that the lawyer is merely a vessel for the client) is known as 'bleached out professionalism'. We wonder, however, whether the idea of the bleached out professional creates a canvas onto which heteronormative presumptions get painted. Here, for example, $40 \%$ of our survey participants had lied about their sexuality in a work context, and $58 \%$ had actively concealed their sexuality.

"I have not actively lied, but I have lied by omission, particularly if asked "do you have a girlfriend?" The answer "No" confirms the assumption of heterosexuality inherent in the question." Survey9768

"I have certainly played the pronoun game." Survey9820 
Interestingly, a number of interviewees shared that they 'outed' themselves by referring to their husband/wife/boyfriend/girlfriend and there was a suggestion that the "good gays" (those conforming to heteronormative standards) were more acceptable at the Bar. Here, when we looked at the survey data in more depth we saw that those who were in relationships were more likely than those who were single to be out at work.

The Bar regulator, the Bar Standards Board (BSB), undertakes regular diversity data collection and monitoring exercises (both stand alone and via chambers). In the latest exercise, published in December 2016, only $31.8 \%$ of the Bar disclosed their sexuality to the BSB. This compares with $99.9 \%$ willing to disclose their gender and $91.8 \%$ their ethnicity. Strikingly, $85.2 \%$ of our survey respondents said that they had disclosed their sexuality to the BSB as part of its data collection exercise. This may say something about LGBT+ barristers (i.e. that they are more willing than heterosexual barristers to disclose their sexuality in official statistics) and/or something about our sample (i.e. they were a selfselecting, happy-to-disclose group).

Just under a third of our survey participants (32\%) were considering, or would consider, applying to take silk and become a Queen's Counsel. However, $20 \%$ of those so considering said that they would not disclose their sexuality as part of the application process. One survey respondent suggested they would not disclose their sexuality because LGBT+ barristers were perceived as less aggressive and this would be a negative in relation to taking silk. We had vigorous push back on this point in our interviews.

\section{Sexuality and Practice}

Half of survey participants agreed or strongly agreed that their sexuality had some connection with their professional lives (41\% disagreed or strongly disagreed; $9 \%$ were undecided). A minority (15\%) felt their sexuality had influenced their choice of practice area. Double that number thought that their choice of chambers had been influenced by their sexuality.

The interviews and qualitative survey data brought out two opposing views on why it might (or might not) be important to be out at work and why (or why not) sexuality might have some connection to practice. The first bundle of ideas goes to the concept of 'bleached out professionalism' discussed above, and to risks to career.

"My sexuality is completely irrelevant to my clients (lay and professional) and there is absolutely no need for it to come up. It's not a question of being "out" or not, it's about whether my clients should know anything about my private life." Survey0998

The second set of responses suggested that the personal and the professional could be intimately connected. This was for four reasons. First, a sense that a barrister was a better barrister when they brought the whole of themselves to their work. Second, various of our interviewees suggested that, for their own mental health and wellbeing, it was important for them to be out at work and to see that their sexuality was in some way connected to their practice.

"I think it's really important because I remember how unhappy I really was in university when I wasn't out and the efforts I made to lie about it... People are human beings, they're going to ask you about your life, you know, where you go, what you do and there's only so far you can continue to avoid it." B23 
Third, a number of our interviewees suggested that, by being LGBT+, they were innately more able to understand the differences of other people and how being different could come with negative impacts. This idea, of the empathetic LGBT+ barrister, was a strong narrative in our interviews.

"I guess it gives me an appreciation of being the other. A lot of the people we'll be working with will be outsiders of some point of view in some way." B14

"It gives me a strong sense of what you might call liberalism, tolerance, equality, those kinds of values, which are definite drivers for the choice of work I do. "QC54

Finally, we were struck by how few barristers saw the potential financial benefits of linking their sexuality and their practice (what the wider literature calls the "business case" for diversity). Only a quarter of our survey participants felt they have ever been instructed because of their sexuality. In the interviews, many seemed surprised when we asked them if they had ever sought to use their sexuality to win work (for example by networking with LGBT+ instructing solicitors).

"I think that they might be a little insulted if I so transparently, effectively said, go on, send me more work because we're both gay" B19

Interestingly, a number of the pupil barristers and students made it clear that knowing that the chambers in which they undertook their pupillage was LGBT+ friendly was an important matter for them:

"I would have chosen a different chambers for pupillage... I received more than one offer... if I had known about their attitudes to homosexuality before making my decision." Survey5196

In a market where the 'best' chambers are competing for the 'best' pupils, a chambers actively signalling that it is welcoming to LGBT+ pupils may have some competitive advantage.

\section{Networks and Role Models}

Half of those who completed our survey were members of BLAGG, the Bar Lesbian and Gay Group. Just under a third (30.4\%) were members of FreeBar, and $11.6 \%$ were members of InterLaw. When we explored the potential benefits from legal profession related LGBT+ networks, various positives were put forward. These included the promotion of LGBT+ issues and inclusiveness in the workplace, visibility and awareness raising, forms of support for members, and social activities. Some, however, pushed back against such networks for focussing too much on the social.

"Unfortunately I feel that these groups have a tendency to become drinking societies rather than doing much to support LGBT+ members of the Bar." Survey9878

"I can remember going to a BLAGG meeting when I was a pupil and it was in London on a Saturday and thinking, 'Jesus, this is all gay men who know each other. It's got absolutely nothing to do with me' and I never went again. " QC56

Others however saw value in the social function, seeing as it tied in with the supportive function and the availability of role models.

"I met obviously lots of people at the FreeBar event, that's a huge, that really has been a huge thing this year because it's been the only LGBT thing that's happened to me, at the Bar... I did not have anything like that... in terms of knowing and like chatting to gay members of the Bar, especially throughout the 
profession. The people I know in Chambers... I kind of know they're gay, but I don't think it's something I've ever particularly spoken with them about. Not like, you know, kind of 'oh let's be kind of chummy because we're both gay in Chambers'. Whereas at FreeBar it felt like that was much more the aim, kind of that we are part of a community, and so that was the reason that everyone was there and so that... fronted the issue and that was really nice." S41

Interviewees suggested that networks could play an enhanced role by increasing their function to include: provision of advice to chambers on signalling LGBT+ friendliness to students; enhancing visibility of the LGBT+ community at the Bar; outreach work; research, policy and campaigning work; and advice or support in circumstances of discrimination or homophobia. Interestingly the only strong signal of a chambers' LGBT+ friendliness that student interviewees mentioned was links to these networks.

Others suggested that the outreach role was something that more properly sat within the duties of the Inns or the Bar Council:

"The Inns are just getting with the programme. I don't know how much they do with students. I've no reason to think they're doing very much... Because it's not apparent that, you know, the Bar is gay friendly. And until people looking at it from outside or freshly plonked in the middle of it know that, like that, then not enough has been done." QC39

The vast majority of survey respondents either agreed or strongly agreed that LGBT+ role models are important at the Bar (87.9\%) and in the judiciary (89.5\%). In interviews, it was apparent that this had been most important to respondents at the point at which they were entering the profession or a new chambers. The importance of role models representing intersectional concerns was also discussed by some respondents, as was the need for role models across a range of levels of experience at the Bar.

"I find it frustrating if people, particularly in positions of leadership roles or power or role model situations, choose not to [be out] because I think that is not doing a public service to the generations who come behind, who need, for the thing I was talking about before, they need to realise that actually there are probably gay men in every barristers' chambers, but if all the gay men in those other barristers' chambers choose to not disclose those chambers will forever remain apparent pockets of lack of gay men." QC54

The value of such role models was seen primarily in their visibility. Some comments suggested that to be a role model an LGBT+ barrister or judge didn't necessarily need to provide an example or a model which could be emulated, but rather was simply, by their presence, providing evidence that a career at the Bar could be achieved by an openly LGBT+ individual. 


\section{ABOUT THE RESEARCHERS}

Marc Mason joined Westminster Law School in 2013 following a period of practice as a Family Law Barrister specialising in child protection. His current research looks at the regulation of the legal profession and legal service markets, with a focus on the Bar of England and Wales. Marc has previously worked on research projects funded by the Ministry of Justice, the Foreign and Commonwealth Office, and the Nuffield Foundation

Dr Steven Vaughan joined UCL Faculty of Laws in the summer of 2017. An ESRC 'Future Research Leader', his research involves various aspects of diversity in the legal profession, among other matters. Steven sits on the Policy Committee of the Solicitors Regulation Authority and spent almost a decade in practice as a corporate finance solicitor in the City. His current work is concerned with professional independence and professional identity formation. 

UCL Centre for Ethics and Law

Faculty of Laws

Bidborough House

38 - 50 Bidborough Street

London WC1H 9BT

http://www.ucl.ac.uk/laws/law-ethics/
Centre on the Legal Profession Westminster Law School University of Westminster 4 - 12 Little Titchfield Street London W1W 7BY

https://www.westminster.ac.uk/ centre-on-the-legal-profession 